\title{
Research on the Transformation and Innovation of Securities Brokerage Business under the Background of Internet Plus
}

\author{
Jinjiao Wu \\ Department of Finance and Business, Wuhan College of Foreign Languages and Foreign Affairs, Wuhan \\ Hubei, 430083, China
}

Keywords: Internet plus background, Securities brokerage business, Transformation innovation research

\begin{abstract}
The development of information science and technology has made the Internet a well-known term in the world. In this era of being flooded by the Internet, there is no doubt that there has also been a major shift in all walks of life in China. Especially for the securities brokerage firms, finding new breakthroughs and directions for transformation is the most important task. This paper, based on the Internet + background, starts to study securities brokerage business transformation innovation, and then studies on the Internet plus securities brokerage business transformation and innovation of countermeasures.
\end{abstract}

\section{Introduction}

The advent of the Internet can be said to have changed the entire world. It is precisely because of its rapid development that the business model of all walks of life in our country will start to face a major transformation. Especially for securities brokerage companies, it is clear that the traditional securities business model and philosophy have completely failed to meet the needs of the current Internet age, so these securities brokerage firms in order to fierce competition in the market to gain a firm foothold and sustained stable development, we must immediately realize the transformation. Combined with the current background of the Internet + , we must explore a new business model of "Internet + Securities" as soon as possible and make the Internet brokerage business a breakthrough in the transformation and innovation of securities companies. The only way to adapt to the current trend of social development as soon as possible in order to obtain the opportunity to accept the challenge, so as to enhance the market competitiveness and influence of securities brokerage companies in the Internet + environment, and achieve smooth strategic transformation and innovation. In short, the continuous upgrading and development of Internet technology will be an innovation for the development of China's securities brokerage firms, which has a very strong practical significance.

\section{Strategic Transformation of Securities Brokerage Business under Internet + Background}

\subsection{Requirement Analysis on the Strategic Transformation of Securities Brokerage Business under the Background of Internet +}

The analysis of the requirements for the strategic transformation of the securities brokerage business under the Internet + background is mainly discussed from the following four aspects:

First, the feasibility of securities brokerage business getting closer to Internet finance. With the development of the Internet, the number of netizens in China is also constantly rising, and gradually showing a trend of linear growth. It is precisely because of China's advanced Internet technology and the large number of Internet users for the traditional securities brokerage business transformation provided the necessary conditions; In addition, the vast majority of Internet users in our country have a good online trading capabilities. Because of the convenience and intuitiveness of online transactions, many Internet users have joined the ranks of mobile phone stocks. People can grasp and analyze the trend of the stock market anytime, anywhere. 
Second, the need to improve customer service experience. For customers to create more superior service experience and personalized consumer demand for the securities brokerage business transformation is very important. Often the user can have a satisfying online trading experience, which is directly related to the customer's impression and trust in the company. Therefore, in order to enhance customer experience faster, we must meet the following points. Respectively, to provide convenient and simple securities trading functions, create an open Internet securities trading platform and provide payment functions.

Third, the main existing form of securities brokerage business under the background of Internet +. With the rapid development of the Internet, mobile terminals such as Weibo, Forums, WeChat and QR codes gradually emerge. This totally subverts the traditional securities brokerage business but also makes the connection between the Internet and the securities brokerage business more and more closely. At present, in the Internet environment, the main forms of securities brokerage business in our country include multiple forms such as network financing, virtual currency and payment and settlement.

\subsection{Cost Leadership Strategy Research on Securities Brokerage Business}

First, the overall goal of the strategic transformation of securities brokerage business. Regardless of any business, having a complete set of total cost leadership strategies means achieving competitive advantage by reducing product costs. Often the lower cost shows the lower one, making it easier to gain market advantage. For securities brokerage companies, it is bound to establish a more comprehensive and systematic brokerage business network, try to expand the range of outlets to achieve the ultimate goal of the total cost of securities brokerage business, and ultimately to ensure that customer assets to achieve the preservation and value-added.

Second, the total cost of securities brokerage business strategy leading the way. Securities brokerage business to achieve the overall cost of the leading strategic model is more applicable to some of our country's large securities companies or enterprises. Because these securities companies often have massive client resources and have worked hard for many years in the securities industry with ample experience in development. Therefore, these large securities brokerage companies in order to achieve the total cost of the leading strategic goals, you can proceed from the following steps: First, the establishment of a system of efficient securities marketing management platform. This will facilitate the securities brokerage business in an orderly manner for marketing, account opening and management; secondly, to ensure that securities brokerage business and other businesses consistent. With the consistency of brokerage business and other businesses, reduce the total cost of securities brokerage business; Finally, the synergy between the core business. It can be said that the future of our country's large securities companies have a basic background of a strong financial holdings, and the company's internal business lines are basically between the synergies.

\section{Research on the Transformation of Securities Brokerage Business under Internet + Background}

\subsection{Development trend of securities brokerage business under Internet + background}

\subsubsection{Securities management to de-physical channelization}

The rapid development of the Internet has brought tremendous influence and challenge to the traditional securities brokerage companies. According to relevant research and studies, in order to adapt to the current background of China's information development as quickly as possible, most of the banks in our country have adopted the methods and measures to replace the counter service with the counter service, and the users are basically biased towards the online banking service, Go to the bank for related business. Not only banks, many securities brokerage firms also suffered the same impact. The traditional securities service channel has been difficult to adapt to the development trend of the society. In the future, the service channel of securities operation will be characterized by physical channelization, that is, the development of an online securities broker model with the virtual 
channel as its main mode of operation. This state of the securities business model in the securities business premises from the previous physical outlets or sales department turned to the online Internet, and these securities physical outlets or the securities entity business department is not responsible for the functions of the previous account opening service, but for securities investors to provide value-added services outside the Internet and the company's image display business. In general, one of the development directions of brokerage business of securities companies in the background of Internet + is de-physical channelization.

\subsubsection{Removing PC from securities trading}

The so-called removing PC from securities trading essentially refers to the securities brokerage business in the mobile Internet transactions. The development of the Internet has led to a completely new area, namely the mobile internet. Its emergence has brought great convenience to people, making mobile smart terminals such as mobile phones, computers and iPads become an important part of people's work, life and study. It is reported that the proportion of Internet users using a smart phone online accounts for more than $80 \%$ of all Internet users in China. And the number of customers who use ICBC Mobile Banking to handle their business is two-thirds of the total number of online banking customers. Therefore, in order to grasp the development opportunities in the current market and adapt to the development environment of society as soon as possible, it is necessary to seize the securities brokerage business in the mobile Internet market in a timely manner Capacity, toward the direction that removing PC from securities trading.

\subsubsection{Business big data information of securities brokerage}

The advent of the Internet era is the inevitable trend of the development of information science and technology, but also the premise and technical basis for the emergence of big data. Securities brokerage business can be said to have been an important impact of big data, and even can be said that the transformation and innovation of securities brokerage business revolves around big data. In detail, the securities brokerage firm's transaction is actually the gathering point for both companies and customers to trade. Transaction information formed during the transaction and financial information, logistics information and other information and data is the most important securities brokerage firm's assets and income. Because this data information after big data integration and mathematical modeling, basically equivalent to the formation of a comprehensive information network. Some securities brokerage companies can find the law of market changes and securities business from this comprehensive information network. In this way, not only the business needs of financial securities are basically met, but also the securities brokerage companies are gradually promoted to the information transformation The process. Therefore, we must make full and efficient use of the technical means brought by the Internet and through the big data, accurately find the profit-making points for the future development of the securities brokerage business.

\subsection{Countermeasures of Transformation of Securities Brokerage Business under Internet + Background}

\subsubsection{Securities wealth management integrated model}

At present, large or medium sized stockbroking companies in our country generally have more customer resources. Nowadays, more and more customers are starting to lose their jobs. The root cause of this is that the current market is getting heated with the commission war and the key issues are these Securities brokerage firms do not take low commission measures to attract customers. In order to improve the current development mode of securities brokerage companies and enhance customer service experience, we should attach great importance to the application of Internet and related technical means in securities brokerage business, and promote the smooth transition and innovation of securities brokerage service to wealth management. The specific implementation path can be explored from the following aspects:

First, innovative service model, to consolidate customer stock. For large-scale securities brokerage firms that can make full use of their own full range of business qualifications and strong technical 
strength and other strengths and advantages, innovative research and development and the establishment of a variety of securities services, for example, to create a comprehensive account system to develop and improve the basic Consumer spending capabilities and the establishment of the Internet business platform, in order to meet the individual needs of investment clients, diversified needs, provide targeted quality services.

Second, upgrade securities brokerage business, in full swing financial management. How to realize the successful transition of securities access service to wealth management based on having sufficient client resources and give full play to the core advantages of securities brokerage business need to start from these aspects, namely to establish a multi-level and multi-series cross-market product library, To meet the individual needs of investment clients; organize and cultivate specialized securities wealth management team, timely detection and control of the actual needs of customers; create a scientific system of wealth management support system, experts and technical platform from both the analysis of resources Orientation to grasp the customer's information, to provide standardized, personalized service experience.

\subsubsection{Securities brokerage company boutique featured mode}

For small and medium-sized private securities brokerage firms in our country, there may be a big gap compared with the large securities brokerage firms that have the background of state-owned enterprises or state-owned enterprises in terms of the scale of operation, the number of securities outlets and the reserve of professionals. Therefore, some small and medium-sized private securities brokerage companies need to solve the most immediate problem is the company's profit model and the amount of customers. How to explore the new profit model and characteristic service in the current Internet + background so as to realize the innovation and transformation of the securities brokerage business needs to be focused on the following aspects for analysis and exploration.

First, take the initiative to reduce commission, the introduction of a wide range of customer traffic. Many large securities brokerage firms in our country are more inclined to self-build network service platform, which is also different from other small and medium securities companies. These small and mid-size brokerage houses often choose to work with Internet giants to take full advantage of the massive customer data they provide on the internet platform and then promote them through online banking and offline consulting and co-branding. This approach helps securities firms, especially small and mid-size brokerage firms, to introduce more customer traffic at the lowest cost and to leverage the benefits of cloud services and other Internet technologies such as big data to enhance customer service experiences.

Second, give full play to their own advantages and create a refined business model. Especially for the small and medium securities brokerage companies in our country, we should take into account our own actual development scale and operation conditions, fully exploit our own potential and give play to our own advantages to find the most suitable business model for our own future development. Whether listed companies or private enterprises, identify business positioning, in a specific market to do more big and small is the most crucial and most important. With the cooperation with the Internet industry, small securities brokerage companies can take advantage of its strong IT technology to provide customers with the best quality service experience while quickly capturing the market and improving the securities brokerage business. This professional boutique business model of securities is also the key to the successful transition of securities brokerage business.

\section{Conclusions}

To sum up, the transformation of securities brokerage business under the background of Internet + is not only an inevitable choice for social development, but also the only way for securities brokerage companies to develop for a long time. Under the coexistence of this opportunity and challenge, reform and innovation are the only ways to successfully gain a foothold in the market. Although most of our securities companies are in full swing to carry out transformation and innovation strategy, and strive to explore the securities brokerage business in the Internet application and realization, hoping to find a new business model in line with social trends, but we also want Time and clearly recognize 
that the Internet + securities innovation model in China's development is still in its infancy, may face great risks, so in the choice of securities brokerage business in the Internet + environment, the direction of development, we must fully consider To the company's own business status quo, combined with the actual situation in transition innovation, in order to reduce the risk and increase the chance of success of the transition.

\section{Acknowledgements}

Research Project of Hubei Provincial Department of Education Research on Transformation and Innovation of Securities Brokerage Business under the Background of Internet Plus Project No. B2016587.

\section{References}

[1] Zhu Nanxi, Research on the Transformation and Upgrading of Brokerage Business in China 's Securities Companies under the Background of Internet Finance, Yun'nan University, 2015-05-01.

[2] Zhang Wenqi, Research on the Strategic Transformation of Brokerage Business of China Securities Corporations from the Perspective of Internet Finance, Beijing Jiaotong University, 2014-06-09.

[3] Qian Yudong,Research on the Transformation of Brokerage Business of China's Securities Company under Internet Finance - A Case Study of Huatai Securities, Statistics Science and Practice, 2016-08-25.

[4] Kan Ge, The Strategy of Small and Medium Sized Brokers in Internet Finance, Shenzhen University, 2017-06-30.

[5] Li Guanglong,Probe into the Transformation of Securities Brokerage Business under Internet Finance, Guangxi University, 2016-05-01. 